\title{
ISLAM AND FEMINISM THEOLOGY
}

\author{
Muhaemin Latif \\ Faculty of Theology and Philosophy, Alauddin State Islamic \\ University, Makassar, South Sulawesi, Indonesia \\ Jln. H. M. Yasin Limpo, No. 36 Samata Gowa \\ Email: muhaemin.latif@uin-alauddin.ac.id
}

\begin{abstract}
This article examines the relationship between Islam and feminism theology. Both Islam and feminism are strongly important to be discussed in the field of Islamic discipline, especially the issue of women liberation. As can be seen in the classical theology, the issue of feminism is not the main concern among the Muslim Intelectuals. Some argue that Islam do not take into account the liberation of women, they even think that Islam assume women as the "second creature". In addition, the creature as well as the perfection of women extremely depend on the existence of men. This research aims at answering these assumptions. The research suggests that feminism are the foundations of Islamic teaching. Historically, the emergence of Islam in Arab peninsula illustrates the women liberation from the Arabic doctrine and tight tradition. This article believea that the positioning of women in line with men was influenced by the fallacies of interpretation toward Koran and prophet tradition. A number of quranic excegeses are genderly biased. So, this research proves that liberating women from dogmatic tradition is rethinking the products of interpretation either in the Koran or prophet tradition.
\end{abstract}

Keywords: Feminism, Theology, Liberation, Dogmatic Tradition 


\section{Introduction}

Generally speaking, the term "feminism theology" is not originially from Islamic history. This terminology is strongly associated with Christian traditions, especially those described in the Bible that God is identical to men or in Christian terms ${ }^{2}$ as a "father". ${ }^{3}$ In other words, the church tradition tends to place women as beings whose presence is very dependent on men. The emergence of feminism in this context is autocritical of church authorities who are not sensitive to women's position. But if explored further, the impartiality of women's sensitivity does not only occur in the Christian tradition, but long before in the classical Greek tradition has occurred, for example the term Goddess who shows the god of women is also very dependent on the gods as their life partner. Goddesses are deemed unable to carry out their duties without the presence of the god beside them. ${ }^{4}$ This means that the problem of inequality and imbalance

${ }^{1}$ This term is initiated from French language "feminist" which further adopted into English feminism. It is coined in 1880an by Hubertine Auclert, advocates women rights in French. That is popularly recognized in 1890an. For further information, please see Nancy F. Cott, The Grounding of Modern Feminism (USA: Vail Ballau Press, 1987), p. 14.

${ }^{2}$ Michael Amaladoss, Life in Freedom: Liberation Theologies from Asia, diterj. Oleh A Widyatmartaya dan Cindelaras dengan judul, Teologi Pembebasan Asia (Yogyakarta: Pustaka Pelajar, 2001), p. 245.

${ }^{3}$ Term "Father" is one part of the concept of the trinity that is understood by Catholic Christians. Besides "father", they also know "son" and "holy spirit".

${ }^{4}$ Michael Amaladoss, Teologi Pembebasan Asia, p. 65. 
between men and women has colored the flashback of theological developments since the past until now.

According to Amaladoss, in the Asian context, feminism can be divided into three groups. First, liberal feminism which targets the movements of urban middle class women who fight for equality of women and men from the aspect of salary, position as leader and type of work. Second, feminism in left political movements that defines work in the private industrial sector, not domestic work. Third, the feminism of the unorganized lower class women's movements such as women workers, female fishermen, women farmers who demand economic improvement and fulfillment of their daily needs. ${ }^{5}$ The birth of these three groups of feminism cannot be separated from the culture of patriarchy which literally means "the leadership of the father". Father is seen as a figure who controls family members, economic resources and at the same time the highest decision maker. Patriarchism, thus, places men in a higher position than women. Even worse, patriarchism is also seen as the root of a misogynistic view (an anthropological term that tends to underestimate women's position or even hate it). ${ }^{6}$

Feminism in the context of the modern world is not only seen as a liberation movement of women related to the social and political traditions of a particular society, but

${ }^{5}$ Michael Amaladoss, Teologi Pembebasan Asia, p. 63.

"Nurul Agustina, "Gerakan Feminisme Islam dan Civil Society" adopted in Kamaruddin Hidayat and Ahmad Gaus Af (Ed.), Islam, Negara dan Civil Society (Cet; Jakarta: Paramadina, 2005), p. 378. 
feminism has also penetrated the world of theology which later developed into the term theology of feminism. This term has developed since 1960 in North America which has been used as a scientific discipline in various well-known universities. The link between the feminism movement in its relation to theology has become the author's reference in highlighting the liberation side of women in Islam.

The position of women themselves in Islam is also a serious concern for the theology of liberation in Islam for contemporary Islamic intellectuals. Injustice to women due to systems and traditions that do not favor them has almost never been a conversation with classical Islamic theology. This condition causes why in the tradition of classical Islamic theology, the defense of women is not included in the priority scale, because it is considered to have no theological relations and implications. Theological doctrines like this lead women to subordinated spaces that are marginalized and do not need to get justice. Women are considered creatures inferior to men's superiority. In the terminology of Simon de Beavoir, women are "second sex" after men. ${ }^{7}$ In other words, there is no concept of equality between men and women. Consequently, the continuity of injustice that is born of various fetters of tradition, culture, even theological normativity continues. At this point, the link between Islam and the feminist theology should be taken seriously.

${ }^{7}$ Asghar Ali Engineer, The Qur'an and Modern Women and Modern Society, translated by Agus Nuryatno, Pembebasan Perempuan (Cet. II; Yogyakarta: LKiS, 2007), p. 1. 
The spirit of women's liberation itself is not present in a vacuum. Look at how the struggle for women's liberation in the European and American context is based on the events of the second world war. This role has devastated social and humanitarian structures and has a profound effect on the world of industrial economics. The large number of casualties caused by the war, mostly from men, has become a problem for the industry. They lack manpower in managing their industry. This condition must automatically involve women as industrial workers who are not many victims of the second world war. From here, it starts how women leave the world of domestic work (households) to the public space. The increasing number of industries also automatically increases the need for female workers. Women then play an important role in various industries while increasing awareness of their equality with men. They then become independent and do not always depend on men. This independence underlies the birth of women's liberation movements campaigned in Europe and America in the 60s. ${ }^{8}$

\section{Historical Roots of Islamic Feminism Movement}

Unlike what happened in the West, the feminism movement in Islam has been born since Islam came into the sixth century $\mathrm{AD}$. In other words, the advent of Islam is also the beginning of the feminist movement. The Prophet Muhammad himself acted as the initiator and "carrier" of the feminist flag of

\footnotetext{
${ }^{8}$ Asghar Ali Engineer, Pembebasan Perempuan, p. 2.
} 
various shades of classical Arab tradition. Nabi Muhammad S.A.W. not only being revolutionary in the word but also revolutionary in action. He has freed women from the arrogance of the Arab traditions and lifestyles. History has noted how women in the pre-Islamic Arabs are likely to become merchandise ready for sale at any time. They are offered as a property. In the description of Maulana Muhammad Ali, the woman left by her husband, her older son or other family member has the right to have it, marry him if they love it without giving a dowry or marriage to someone else, or forbid them to marry at all. Not only that, burying newborn girls has become a tradition of pre-Islamic Arab society. They consider that girls are only a family economic burden in the future and fears will be a form of insult and reproach that is often caused by girls captured by enemy tribes and subsequently inflicted the pride of their kidnappers in front of their parents and brothers.' This tradition was exacerbated by the habits of pre-Islamic Arab society about the absence of restrictions on the number of wives that men could have. In al-Tabari's account, as quoted by Engineer, an average member of the Quraysh tribe has ten wives. Some married four, five, six or even ten wives and asked who could stop him from marrying more than anyone else. $^{10}$

${ }^{9}$ Asghar Ali Engineer, The Rights of Women in Islam, translated by Farid Wajidi and Cici Farkha Assegaf, Hak-Hak Perempuan dalam Islam (Cet. II; Yogyakarta: Pustaka Pelajar, 2000), p. 32.

${ }^{10}$ Asghar Ali Engineer, Hak-Hak Perempuan dalam Islam, p. 32. 
The position of women in the context of pre-Islamic Arab society is indeed very concerning. They become victims of oppressive traditions and place them in the subordinate areas of men. The arrival of Islam then became a new spirit for women by placing their degrees on par with men. There is no difference in status between men and women. Both come from the same element, namely nafsin wahidah (one soul) as illustrated in QS al-Nisa / 4: 1 as follows:

Meaning:

O mankind, fear your Lord who has created you from one's self, and from him God created his wife; and from both of them God multiplies many men and women. and fear Allah that by His name ye ask one another, and (guard) the bond of peace. Surely God is always watching over you. ${ }^{11}$

The above verse has brought a great revolution in the Islamic tradition. Men and women not only come from the same source, but also Islam has empowered women and given them equal status with men. It's just that, the expansion of Islam into various major regions in various places such as Syria, Egypt, Persia, and other regions in Central Asia, their traditions which still dominate women still remain which in turn has a detrimental effect on the status of women. ${ }^{12}$ Even at this time, various kinds of hadith that appeared and tended to discredit women so that it was sometimes difficult to

11Departemen Agama RI, Al-Qur'an dan Terjemahnya, p. 99.

${ }^{12}$ Asghar Ali Engineer, Pembebasan Perempuan, p. 9. 
distinguish between the Sunnah of the Prophet and the customs of the Arabs and the customs of the ancient (foreign) nation. ${ }^{13}$ In addition, the interpretation of various hadith histories also triggers the perception that women are under the shadow of men. One of the traditions that deserves to be highlighted is that the creation of women comes from the male ribs. ${ }^{14}$ This hadith has placed women in male subordination so that there is no equality between men and women. ${ }^{15}$ The concept that Eve was created from Adam's ribs generally exists among Christians. ${ }^{16}$ At least there are two arguments that can be taken to count the hadith. First, that the Qur'an has given the highest respect and appreciation to humanity and humanity without distinguishing between men and women. Second, the existence of gender differences between men and women is natural. It's just that these differences do not create differences in the area of gender. ${ }^{17}$

${ }^{13}$ Armahedi Mahzar, "Wanita dan Islam", kata pengantar in Fatima Mernissi, Women and Islam: A Historical and Theological Enquiry, terjemahan Raziar Radianti, Wanita di dalam Islam (Cet. I; Bandung: Pustaka, 1994), p. xii.

${ }^{14}$ Although the hadith is in the authentic category, the Engineer is still criticizing him by saying that this hadith was included in the category of misoglys (traditionally discredited women). This Hadith narrated by

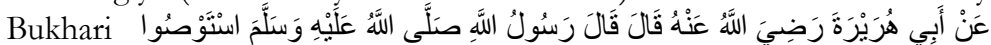

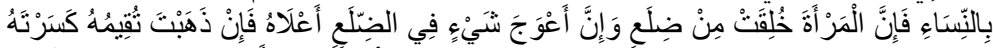

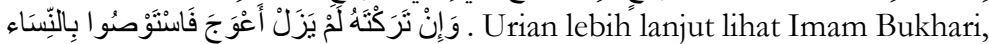
Shabih Bukhari, dalam program Lidwa Hadis, Lidwa Pusaka Software, t.th, hadis no. 3084.

${ }^{15}$ Agus Nuryatno, “Examining Asghar Ali Engineer's Quranic Interpretation of Women in Islam" Jurnal al-Jamiah, Vol.45.No.2, 2007.

${ }^{16}$ Asghar Ali Engineer, Pembebasan Perempuan, h. 10.

${ }^{17}$ Although the hadith is in the authentic category, the Engineer is still criticizing him by saying that this hadith was included in the category 
In other words, women should not be distinguished from men in the contestation of public roles because of gender differences. The birth of opinions that tend to discredit women is also more influenced by understanding textual religious texts. Even though according to him, the Qur'an is not only viewed from the aspects of normativity but also contextual verses are also a major consideration in interpretation. The spirit of women's liberation which is clearly stated in the Qur'an gradually fades because the patterns of interpretation are not contextual and tend to ignore the substance of the verses of the Qur'an. ${ }^{18}$

Musdah Mulia illustrates that there are at least three factors that cause the emergence of a religious understanding that is not female-friendly or gender-biased. First, Muslims generally understand religion more dogmatically, not based on critical and rational reasoning, especially religious knowledge that explains the role and position of women. No wonder the understanding that arises is very ahistorical. Gender relations are seen as something given, not socially constructed. Second, in general, Islamic society obtains religious knowledge through lectures from ulama who are generally very gender biased and biased towards patriarchal values, not based on critical and in-depth studies of the original sources. Third, the

of misoglys (traditionally discredited women). This Hadith narrated by Bukhari Agus Nuryatno, "Examining Asghar Ali Engineer's View..". Women in this case become objects, while men become the subject. The most important of these verses is that women cannot be leaders for men. They only deserve to be led by men who act as guards.

${ }^{18}$ Asghar Ali Engineer, Pembebasan Perempuan, p. 11 
understanding of the relations between men and women in society refers more to textual understanding of sacred texts, ignoring the contextual aspects that prioritize egalitarian principles and are accommodative of human values. Islam is not just a collection of texts, but a set of divine guidelines that are revealed for the happiness and benefit of all human women and men. ${ }^{19}$

Early Islamic history has shown concretely how the Prophet Muhammad. has made radical changes to the conditions of Arab society, especially related to the position and position of women. Among other things, the prophet taught the necessity of celebrating the birth of a baby girl in the midst of an Arab tradition that saw the shame of the birth of a baby girl.

The concept of equality of men and women is not only seen from the explanation that they come from the same source but also their right to inherit is also a great revolution in the Islamic tradition. As explained in Surah al-Nisa / 4: 7 as follows:

Meaning:

For men there is the right of the inheritance of their parents and their relatives, and for women there is a share of the inheritance of their parents and relatives, whether small or large according to the prescribed part. $^{20}$

${ }^{19}$ Musdah Mulia, "Perempuan dari Patriarkhisme Islam" kata pengantar dalam Syafiq Hasyim, Bebas dari Patriarkhisme Islam (Cet.I; Yogyakarta: KataKita, 2010), p. 18.

${ }^{20}$ Departemen Agama RI, Al-Qur'an dan Terjemahnya, p. 101. 
The verse above, according to Fatima Mernissi, is like a bomb blast for the men of Madinah. This is the first time experiencing a conflict with the Islamic God. Before the verse came down, only the man was entitled to inheritance, while the woman did not have inheritance rights, even she became part of inheritance. The above verse also sparked protests from the Madinah male group at that time which assumed that Islam had too far interfered in inheritance issues, including their relationship with women. This protest was of course reasonable because the tradition of dominating women was rooted in pre-Islamic Arab society at that time. They have become accustomed to living in patriarchal ways and patterns where men become very dominant in the context of their lives while women are always the object of sufferers. In addition to traditional factors, economically, the adoption of a new inheritance system brought by automatic Islam reduces income generated to men because their share is not fully theirs, but must be shared with women. ${ }^{21}$

Thus, the Prophet introduced inheritance rights to women when women were treated only as objects or parts of inherited commodities. Likewise the prophet has made a total correction of the practice of polygamy which has become a tradition of Arab society by limiting it. Even the prophet himself banned his daughter, Fatimah, from being polygamous. ${ }^{22}$ All of these examples indicate the alignments

${ }^{21}$ Fatima Mernissi, Wanita di dalam Islam, p. 151.

${ }^{22}$ Musdah Mulia, "Perempuan dari Patriarkhisme Islam”, p. 19. 
of Islam towards the liberation of women from various constraints of tradition.

The description above also clarifies the positioning of Islam towards the concept of feminism which is now widely developed in the West. In short, long before this theory was born, Islam had given birth to a feminist movement both contained in scriptural texts and practices or traditions initiated by the Prophet Muhammad and then followed by friends and followers.

Although the partiality of Islam towards women is very clear, in practice, there are some practices of Muslims that actually weaken the alignments as illustrated in the following description.

\section{Polygamy as a form of weakening women}

Polygamy is not only a warm discourse in the reality of feminism theology, but in general it has become an issue inherent in the traditions of major religious theologies. Call it in Hindu mythology which describes how Lord Krishna, who is believed to have hundreds of wives, as well as Brahma who lived in many temples also made polygamy part of their theology. Interestingly, the question does not become a problem for women and even considered as something natural or given. The women did not consider themselves victims even the opposite, they considered it a pride or honor to be one of the wives of these gods. ${ }^{23}$ Perhaps this is also, at

\footnotetext{
23Asghar Ali Engineer, Pembebasan Perempuan, p. 108.
} 
least according to the author, which underlies why polygamy in the tradition of classical Islamic theology is not a serious theme to be discussed for theologians. The assumption that polygamy is not always detrimental to women, but instead raises their degree and social status, has made polygamy a theme that does not need to be the priority scale of the discussion of classical Islamic theology. This assumption is based on a statement that says that theology is not born in a vacuum. The social, political and cultural conditions of the community will influence the teachings carried by a school or theology. ${ }^{24}$ Anxiety over the liberation of women, especially from the practice of polygamy, emerged as a result of the wave of industrial revolution which marked the birth of the modern world. ${ }^{25}$ The modern age has expanded the space for public contestation which has not only become the domain of men but has also become the realm of women. The demands of the liberation or equality of men and women go hand in hand with the development of the modern world.

However, the partiality of polygamy in the modern context is due to confusion in interpreting QS al-Nisa / 4: 3 which stated:

Meaning:

And if you are afraid you will not be able to deal fairly with the orphans (when you marry), then marry the other women whom you love: two, three or four. then if you are afraid you will not be able to do justice, then

${ }^{24}$ Asghar Ali Engineer, Hak-Hak Perempuan dalam Islam, p. 74.

${ }^{25}$ Asghar Ali Engineer, Pembebasan Perempuan, p. 109. 
(marry) only one, or the slaves you have. That is closer to no harm. ${ }^{26}$

The above verse is used as a justification for polygamous practitioners and groups who agree to polygamy. One of the souls of the revealed Qur'an is to carry the mission of justice in various forms, such as political, economic, social, and family justice. The justice explored in the above verse confirms how women should obtain justice and equality in the marriage relationship rather than the matter of allowing her to marry more than one wife. In other words, the focus of the above verse does not lie in the number of wives but in the justice that is right for every wife. ${ }^{27}$

If traced further, the verse above is reluctant to accept the institution of polygamy. But because of the contextualization of verses which at certain points still respect traditions that live hundreds of years, the Qur'an limits it to four wives. This maximum limit still invites protests from some of the companions of the prophet, especially if the verse later says that it is prohibited to have more than one wife. However, it is possible to have more than one wife must meet very strict conditions, namely being able to do justice to all of his wives in a variety of matters ranging from small questions to large scale. If this condition cannot be fulfilled, then the Qur'an teaches to marry only one person. Another alternative given by the Qur'an is to marry fully owned slave girls. So

\footnotetext{
${ }^{26}$ Departemen Agama RI, Al-Qur'an dan Terjemahnya, p. 99.

${ }^{27}$ Agus Nuryatno, "Asghar Ali's Views on Liberation Theology and Womens Issues in Islam”, p. 71
} 
according to the Engineer, actually the meaning of the verse above is monogamous. ${ }^{28}$

According to at-Tabari (838-923) and ar-Razi (854925), that the purpose of the above verse is to create fairness both to orphans and to the wives. This argument is clearly seen in the foreground of the verse which deals with justice against orphans. It means being married to just four is the effect of the inability of the orphaned orphans to do justice to them. The property of the orphans is used by his guardian to marry a free woman so that orphans get the injustice of their property. So the position of keeping the orphan's property in this respect is just as important as protecting the welfare of women as wives. Related to this, it is interesting to quote atuaabab's statement, that people are accustomed to assume as a sin if they are not fair to orphans, but do not regard it as a sin unless it is fair to their wives. ${ }^{29}$

It's just that in the present context, according to the author, the discussion about polygamy and the arguments used to strengthen it tend to deny the discussion about the existence of orphans. Most discussions about polygamy lead to the verse section "marry according to your will two, three to four" without deepening the intentions and focus of the

${ }^{28}$ Asghar Ali Engineer, Pembebasan Perempuan, p. 113.

${ }^{29}$ The above mentioned polygamy passage is relegated to the behavior of a man who is the father of a rich orphan, who wants to be married to his wealth, even though the orphan does not like it and has treated it inappropriately. Asghar Ali Engineer, Pembebasan Perempuan, h.113. For further information, please see Muhammad Ibnu Jarir alThabari, Jāmi' al-Bayān fì Ta'mül al-Qur'an,(Cet.I; t.tp: Malik Fahd, 1420 H), p. 531. 
verse as a whole which is actually more conical to the maintenance of orphans in a fair manner. Someone is trapped in the number of wives allowed to four without seeing the previous verse. In other words, understanding one verse is not comprehensive but still partial. So sometimes the conclusions taken also do not include the intent of the totality of the verse. This is what happens in polygamy which increasingly places women in a position that is not free and always under the shadow of male superiority. Women remain a second class creature and do not have the freedom to determine their own future due to the pattern of misinterpretation of the verse on polygamy above.

The ability of men to not do justice to their wives is also clearly emphasized by another verse in the verse 4: 129 which reads:

Meaning:

And you will not be able to do justice between your wives, though you desperately want to do so, so do not be so inclined (to your beloved), so you let the others stack up. And if you make repairs and nurture, then surely Allah is Oft-Forgiving, Most Merciful. ${ }^{30}$

The verse above explains that a person does not have the power to do justice in treating his wives with one another. That is, the message of the Qur'an is actually oriented towards monogamy rather than polygamy. The argument is based on the at-Tabari interpretation which says that it is impossible for

${ }^{30}$ Departemen Agama RI, Al-Qur'an dan Terjemahnya, p. 129. 
a person to do justice to all his wives in matters of love and sex. In other words, these two issues have become very fundamental in marital relations, especially those who practice polygamy. This is the concern of the Prophet Muhammad and Umar in prayer as quoted from the commentary at-Tabari. Umar prayed "O God, I cannot control my heart, except this (ie, same love), I will try to do justice to my wives". Likewise the Prophet's prayer which was also quoted by at-Tabari which reads "O Allah, this is how I share my time with my wives whom I can control, but do not blame me in matters outside of what You have controlled, not me." ${ }^{31}$

In addition to Tabary, Razi also considered that the Qur'anic message about the verse polygamy was interpretable. However, al-Razi, tends to translate the verse to monogamy compared to polygamy. The inability of someone to do justice to his wives on matters of love and sex indicates that God does not require husbands to do justice to his wives because God will never burden someone he cannot do. ${ }^{32}$ Al-Razi cites Mu'tazilah's opinion that because men can not be obliged with something that can not be done then it is not permissible to have more than one wife. ${ }^{33}$

Fazlur Rahman (1919-1988) described the polygamy and the liberation of women. Rahman said, as quoted by Engineer, the Qur'an allows a person to marry more than one

${ }^{31}$ Asghar Ali Engineer, Pembebasan Perempuan, p. 116.

${ }^{32}$ See QS al-Baqarah/2: 286

${ }^{33}$ See Asghar Ali Engineer, Pembebasan Perempuan, p. 116. 
person only to widows and orphans so they feel protected. ${ }^{34}$ Rahman's statement proves that polygamy is actually a form of defense to people who are oppressed both materially and non-materially. Orphans and widows are two social groups that often experience oppression due to not having guardians or assistants. Here is the meaning of the theology of feminism which is full of liberation missions that are echoed to "fight" verse interpretations that indirectly provide space for oppression and reluctance to women. Again such problems are not included in the realm of debate in classical Islamic theology. Muslims today need to reconstruct the meaning of the verse above in order to describe it comprehensively, especially in order to ground women's liberation missions.

\section{The Use of Veil: Discriminating Issue}

In addition to the polygamous question that makes women free, commentary on purdah (veil or veil), ${ }^{35}$ also tends to be dogmatic and in turn has led women to male subordinated areas so that women do not become free to appear in public spaces without being accompanied by their companions or their muhrim. This point has also been a hot topic of feminism theology, although this is not much (avoiding no words) is discussed in the pages of classical

${ }^{34}$ See Asghar Ali Engineer, Pembebasan Perempuan, p. 122.

${ }^{35}$ Veil in English terms refers to the notion "loosely used to refer to a wide variety of head and face covering". In simple terms, a veil which means veil in English is interpreted as a way or model to cover hands and faces. Further description, see Agus Nuryatno, Agus Nuryatno, "Asghar Ali's Views on Liberation Theology and Womens Issues in Islam”, p. 76. 
Islamic theology. Confidence in the obligation to use veils for a group of Muslim women has made Islamic theology anti against injustice to women, especially in developing their creativity. This is where the urgency of feminism theology in presenting justice to women as owned by men.

The use of veils has created freedom and lack of creativity in women. Usually veiled women only hang out and interact with fellow women who are dressed in veils as well. This condition occurs due to beliefs which are still based on normative theological arguments which see theology in ritual aspects only, but do not penetrate the social area which at any time develops following the increasingly complex rhythm of modernity.

Veil itself has become a controversial discourse from various parts of the Islamic world. Some consider the use of the veil as a religious order, some also believe that it is only related to the traditions and habits of certain communities and has nothing to do with religious rituals. Countries like Saudi Arabia tend to side with the first opinion which requires women to wear a veil when they leave home and are severely sanctioned if found not wearing a veil. While in other Arab countries, such as al-Jazair, Morocco, Tunisia, Egypt, the use of veils is only found in rural areas. At the same time, women who live in urban areas wear modern clothes that no longer cover their hands and face. Muslim women in the Arab country tend to be more loose in dressing like Western 
women. ${ }^{36}$ However, Muslim women in Southeast Asian Muslim countries such as Indonesia and Malaysia, the number of shearing wearers is not a large population of Muslims in both countries. Thus, there is no uniformity among the Muslim countries in the duty of the purdah. Each country has its own interpretation of the use of the sheets.

The sheets are not introduced by the Qur'an and the Prophets. Sheets are common among some established classes in the city before Islam comes. It seems that the origin of the veil is not from Arab institutions. Sheets are obtained from Syria, and Palestine, and both are Roman-dominated. In the context of the community, sheets are considered a symbol of status, and are common among the Greeks, Romans, Jews and Syria. There is no special command in the Qur'an to close the face, unless women are told to conceal their private parts and stretch the cloth to his chest. Here is the verse that addressed the question described in QS an-Nur / 24: $31 .^{37}$

Meaning:

Say to the believing women: "Let them hold their gaze, and their lusts, and let them not show their adornment except the (ordinary) appearance of them, and let them cover their veil and do not reveal their adornment except to their husbands or their father, or their husbands father, or their sons, or their

${ }^{36}$ Asghar Ali Engineer, Pembebasan Perempuan, p. 84.

${ }^{37}$ For further information, please see Asghar Ali Engineer, Pembebasan Perempuan, p. 11. 
husbands, or their brothers, or their brother's sons, or the sons of their sisters... ${ }^{38}$

The only way emphasized by the Koran is a dignified manner of dressing and allowing open parts to remain open (illā mā dhahara minhā). There are differences of opinion for Muslim scholars about "what remains open". Some say that the "stay open" is the face and both palms. In other words, the conclusion that what remains open and remains closed is the interpretation of intellectuals. The intellectual then determines clearly how the mechanism and method are closed based on the verse above (illā mā dhahara minhā) based on the local social context. From this, it was concluded that the use of the veil was based more on the traditions and culture of certain communities. In short, veils are more of a sociocultural practice than purely religious. ${ }^{39}$

As with the issue of polygamy, there are at least eight different opinions in the interpretation of the verse. Some friends argue that only outerwear can be exposed, and the entire body including the face and hands must be closed. Another opinion says that a woman can expose her hair (eyes), her ring, her bracelet, and her face. Some say that women can expose their lashes and cheeks. At the same time, there are also friends who argue that a woman's face and two palms are open. Some people argue that women can expose their khizab (mehendi), eyelashes and clothes. Al-ariabari also

${ }^{38}$ Departemen Agama RI, Al-Qur'an dan Terjemahnya, p. 493.

${ }^{39}$ Asghar Ali Engineer, Pembebasan Perempuan, p. 85. 
quoted the opinion of another friend that women should cover their hair, earrings, neck and bracelet. In addition, opinions that allow women to expose their bracelets and necklaces, but have to close the bracelet, hair and shoulders are also quoted by al-ariabari. ${ }^{40}$

In addition, Fakhr ad-Din al-Razi interpreted the verse about the veil. Al-Razi adheres to the opinion that independent women of faith may expose their faces and palms because they are related to their function of buying, selling and paying. Meanwhile, a woman who is not independent (servant) according to al-Razi, can open his whole body except what is between the navel and thighs because the other parts need to be exposed for sale on the market. ${ }^{41}$ Al-Razi's opinion indicates, at least according to the author, that Muslim women in the present context who wear clothes and only cover their navels and between their thighs are classified as non-free or servant women. In other words, these women no longer have the honor of independent women. They are like products that are ready for sale or for commercial needs.

The plurality of the above interpretations asserts that the paragraphs of illa ma dhahara minhā are included in the category of mutasyābihāt verses which require further interpretation depending on the social and cultural contexts of a society. In other words, an understanding of the verse will always be specific cultural. The legal products produced

${ }^{40}$ Asghar Ali Engineer, Pembebasan Perempuan, p. 85.

${ }^{41}$ Asghar Ali Engineer, Pembebasan Perempuan, p. 87. 
by the scholars are not final, but the purpose of the law or the maqāsid of shariah and masālih mursalah remains a major consideration in seeing a legal product. ${ }^{42}$ The use of veil should be seen that Islam only commands to close the genitals or parts of sensitivity of women who do not create lust for men who see it. There is nothing clearly in the Qur'an that describes this sensitive part. The debate over women's hands and palms is also an area of women's sensitivity, certainly requires further discussion. But according to the author, the use of veils has made women as exclusive beings whose freedom is limited by men so that women in their essence have become free. The theology of feminism in this matter needs to be voiced and implemented in the realm of reality. Many women who are intelligent and beat the intelligence of men cannot appear in public spaces because the theology they understand still limits the space for their creativity, including the use of veils. However, according to the Engineer, women do not have to try to be "disrespectful" and dress by ignoring sexual sensitivity in their socio-cultural context.

These two examples of controversial issues are strongly related to feminist theology. These issues are only part of other questions that have put women into inferior beings before men. The issue of impartial distribution of inheritance and doubts about the ability of women to be witnesses is actually also important to be elaborated further. However, these issues do not become a warm discourse in

\footnotetext{
${ }^{42}$ Asghar Ali Engineer, "Shariah, Fatwas and Women's Rights”, Centre for Study of Society and Secularism. Mumbai. p. 2.
} 
classical Islamic theology so that injustice and oppression remain a tradition in women's groups. In this context, the theology of feminism as part of liberation theology should ideally be a framework in freeing women from oppression due to patterns of interpretation that tend to be patriarchal. This problem is meant by the author of how the theology of feminism has been further explained in the texts of the holy teachings of Islam.

\section{Concluding Remarks}

Islam and the theology of feminism are two things that cannot be separated. Both are like two sides of a coin. The presence of Islam in its essence is a form of liberation against women who previously had no place in the traditions of the Arab community. History has recorded how Islamic teachings have dismantled the tradition of partriarchic Arab society to be a society that is friendly to the existence of women. Women are then placed in a respectable position, even the name al-Nisa which means women are enshrined in one of the suras in the Qur'an. This naming is of course not present, everything must be based on philosophical arguments that place women as honorable beings, no longer second class beings after men as many liberal feminists point out. However, the struggle for the liberation of women in the context of Islam also does not want to make women as first class beings who dominate men. For the theology of Islamic feminism, the relationship built in describing the relationship 
between men and women is complementary relations. Both must complement and protect each other.

\section{Bibliography}

Nancy F. Cott, The Grounding of Modern Feminism (USA: Vail Ballau Press, 1987).

Michael Amaladoss, Life in Freedom: Liberation Theologies from Asia, diterj. Oleh A Widyatmartaya dan Cindelaras dengan judul, Teologi Pembebasan Asia (Yogyakarta: Pustaka Pelajar, 2001).

Nurul Agustina, "Gerakan Feminisme Islam dan Civil Society" dalam Kamaruddin Hidayat dan Ahmad Gaus Af (Ed.), Islam, Negara dan Civil Society (Cet; Jakarta: Paramadina, 2005).

Asghar Ali Engineer, The Qur'an and Modern Women and Modern Society, diterjemahkan oleh Agus Nuryatno, Pembebasan Perempuan (Cet. II; Yogyakarta: LKiS, 2007).

Asghar Ali Engineer, The Rights of Women in Islam, translated by Farid Wajidi and Cici Farkha Assegaf, Hak-Hak Perempuan dalam Islam (Cet. II; Yogyakarta: Pustaka Pelajar, 2000).

Armahedi Mahzar, "Wanita dan Islam", kata pengantar dalam Fatima Mernissi, Women and Islam: A Historical and Theological Enquiry, terjemahan Raziar Radianti, Wanita di dalam Islam (Cet. I; Bandung: Pustaka, 1994). 
Imam Bukhari, Shahih Bukhari, dalam program Lidwa Hadis, Lidwa Pusaka Software, t.th, hadis no. 3084.

Agus Nuryatno, “Examining Asghar Ali Engineer's Quranic Interpretation of Women in Islam" Jurnal al-Jamiah, Vol.45.No.2, 2007.

Musdah Mulia, "Perempuan dari Patriarkhisme Islam" kata pengantar dalam Syafiq Hasyim, Bebas dari Patriarkhisme Islam (Cet.I; Yogyakarta: KataKita, 2010).

Departemen Agama RI, Al-Qur'an dan Terjemahnya.

Muhammad Ibnu Jarir al-Thabari, Jāmi' al-Bayān fì Ta'wìl alQur'an,(Cet.I; t.tp: Malik Fahd, 1420 H).

Asghar Ali Engineer, "Shariah, Fatwas and Women's Rights", Centre for Study of Society and Secularism. Mumbai. 